\title{
FUNDAMENTAL IRRADIATION STUDIES ON VANADIUM ALLOYS
}




\section{DISCLAIMER}

Portions of this document may be illegible in electronic image products. Images are produced from the best available original document. 
Operated by

Westinghouse

Hanford Company

for the U.S. DOE

Contract No.

DE-ACO6-76FF02170
A Subsidiary of

Westinghouse Electric

Corporation

P.D. Box 1970

Richland, WA 99352

\section{Hanford Engineering Development Laboratory}

\section{INFORMATION CONCERNING USE OF THIS DOCUMENT}

\section{NOTICE}

This report was prepared as an account of work sponsored by an agency of the United States Government. Neither the United States Government nor any agency thereof, nor any of their employes, nor any of their contractors, subcontractors or their employes, makes any warranty, express or implied, or assumes any legal liability or responsibility for the accuracy, completeness, or any third party's use or the result of such use of any information, apparatus, product, or process disclosed, or represents that its use would not infringe privately owned rights. Reference herein to any specific commercial product, process, or service by trade name, trademark, manufacturer, or otherwise, does not necessarily constitute or imply its endorsement, recommendation, or favoring by the United States Government or any agency thereof or its contractors or subcontractors. 
HEDL-7531

\title{
FUNDAMENTAL IRRADIATION STUDIES ON VANADIUM ALLOYS
}

\author{
B.A. Loomis (ANL) \\ F.A. Garner (HEDL) \\ A.M. Ermi (HEDL) \\ Manuscript Completed: April 1985 \\ Date Published: May 1985
}

\section{DISCLAIMER}

This report was prepared as an account of work sponsored by an agency of the United States Government. Neither the United States Government nor any agency thereof, nor any of their employees, makes any warranty, express or implied, or assumes any legal liability or responsibility for the accuracy, completeness, or usefulness of any information, apparatus, product, or process disclosed, or represents that its use would not infringe privately owned rights. Reference herein to any specific commercial product, process, or service by trade name, trademark, manufacturer, or otherwise does not necessarily constitute or imply its endorsement, recommendation, or favoring by the United States Government or any agency thereof. The views and opinions of authors expressed herein do not necessarly state or reflect those of the United States Government or any agency thereof.

HANFORD ENGINEERING DEVELOPMENT LABORATORY - Operated by Westinghouse Hanford Company, P.O. Box 1970, Richland, WA, a Subsidiary of Westinghouse Electric Corporation. Prepared for the USDOE, Office of Energy Research, Office of Fusion Energy, under Contract No. DE-AC06-76FF02170, B\&R No. AT-15-02-03-04. 
FUNDAMENTAL IRRADIATION STUDIES ON VANADIUM ALLOYS

B. A. Loomis (Argonne National Laboratory), F. A. Garner and A. M. Ermi (Hanford Engineering Development Laboratory)

\subsection{Objective}

The objekt of the effort is to study the response of simple vanadium alloys to fast reactor irradiation and thus provide a bas is for the development of vanadium alloys which are suitable for fusion reactor service and which will also exhibit reduced long-term radio-activation.

2.0 Summary

A joint experiment on the irradiation response of simple vanadium alloys has been initiated under the auspices of the DAFS and BES programs. Specimen fabrication is nearly complete and the alloys are expected to be irradiated in lithium in FFTF-MOTA Cycles 7 and 8.

\subsection{Program}

Title: Irradiation Effects Analysis (AKJ)

Principal Investigator: D. G. Doran

Affiliation: Hanford Engineering Development Laboratory

\subsection{Relevant DAFS Program Plan Task/Subtask}

Subtask II.C.I Effects of Material Parameters on Microstructure

\subsection{Accomplishments and Status}

\subsection{Introduction}

Three commercial vanadium-base alloys ( $V-15 \mathrm{Cr}-5 \mathrm{~T} i$, Vanstar-7 and $V-3 T i-15 i$ ) are currently being irradiated in the FFTF fast reactor in the Materials Open Test Assembly (MOTA). (1) In order to determine the role of each elemental constituent in the phase stability and irradiation response of these alloys, a joint experiment between the DAFS and BES (Basic Energy Science) programs has been initiated.

This experiment will use a series of simple alloys produced earlier in the BES program. No helium will be added to these alloys. Specimens will be primarily in the form of TEM disks although miniature SS-3 tensile specimens will aiso be irradiated for some of these alloys. Irradiation under static lithium in TZM capsules is planned for Cycles 7 and 8 in FFTF-MOTA. In this experiment three capsules are designated as DAFS/BES capsules. Two of these are at level 2 in MOTA $\left(420^{\circ}\right.$ and $\left.600^{\circ} \mathrm{C}\right)$ accumulating $226 \mathrm{dpa} / \mathrm{year}$ and one is at level $1\left(520^{\circ} \mathrm{C}\right)$ at $\sim 14 \mathrm{dpa} /$ year. In addition other specimen subsets will be included in the HEDL ADIP capsules in levels 1,2 and 5. These capsules will also contain one-third size Charpy specimens constructed from $V-15 \mathrm{Cr}-5 \mathrm{Ti}$. 


\section{$5.2 \quad$ Alloy Descriptions}

The alloys can be categorized in the following subsets.

Vanadium Impurity Series: These alloys study the effects of impurity levels and variations in relative amounts of major impurities (carbon, oxygen, nitrogen).

Vanadium-Chromium Series: Ion bombardment data already exist for these alloys which contain chromium Tevels of 10, 15 and 20\%. In addition to phase stability and swelling data, this subset of specimens will provide a correlation between ion and neutron irradiation behavior in a simple vanadium alloy system.

Vanadium-Titanium Series: Ion bombardment experiments on this alloy series are currently in progress. In addition to providing a neutron-ion correlation it is desired to determine the composition of the precipitates that form before and during irradiation.

Vanadium-Other Solute Series: In addition to chromium and titanium, three other solutes were chosen (Ni, W, Mo) to provide a range of elements varying from slow to fast-diffusing species. Both solute segregation and the diffusion relationship to swelling and other property changes will be studied.

$\mathrm{V}-15 \mathrm{Cr}-\mathrm{xTi}$ and $\mathrm{V}-\mathrm{Cr}-\mathrm{Ti}-\mathrm{Zr}$ Series: These alloys will be used to study the interplay between titanium's role in both fabricability and swelling and also to study the consequences of total or partial substitution of zirconium for titanium.

Reference Alloy Series: The three ADIP alloys described earlier will be included for comparison with the results of on-going ADIP studies.

\section{$5.3 \quad$ Status of Experiment}

All of the alloys shown in Table I have been prepared as TEM disks and delivered to HEDL for engraving and encapsulation. A total of 546 disks is currently available for irradiation. Some alloys (V-20Cr, $V-C r-T i-Z n$ series) are still being prepared. Preparation of miniature tensile specimens is also in progress.

\subsection{References}

1. A. M. Ermi, "FFTF Fusion Irradiations-FFTF Cycles 4-6," Alloy Development for Irradiation Performance Semiannual Progress Report for Period Ending September 30, 1984, D0E/ER-0045/13 p. 21 .

\subsection{Future Wark}

Preparation of tensile specimens will continue.

\subsection{Publications}

None. 
Vanadium-Bese Alloye for Irrediation In PFTP

\begin{tabular}{|c|c|c|c|c|c|c|c|c|c|c|c|c|c|c|}
\hline $\begin{array}{l}\text { Reference } \\
\text { No. }\end{array}$ & $\begin{array}{c}\text { Alloy } \\
\text { Compostition }\end{array}$ & $\frac{\text { Pac1lity }}{\frac{T \operatorname{Temp} \cdot\left({ }^{\circ} \mathrm{C}\right)}{\mathrm{DPA}}}$ & $\frac{\text { DAYS }}{\frac{420}{26}}$ & $\frac{A D I P}{420}$ & $\frac{\text { ADIP }}{\frac{420}{26}} \frac{{ }^{2}}{26}$ & $\begin{array}{r}\frac{\text { ADIP }}{420} \\
\frac{52}{\text { of } 3-0}\end{array}$ & $\begin{array}{l}\frac{\text { ADIP }}{420} \\
78 \\
\text { Dice }\end{array}$ & $\frac{\frac{\text { DAFS }}{520}}{\frac{16}{10}}$ & $\frac{\frac{3}{520}}{\frac{501}{20}}$ & $\frac{\frac{\text { ApIP }}{600}}{\frac{10}{100}}$ & $\frac{\frac{A D I P}{600}}{30}$ & $\frac{\frac{\text { DAPS }}{600}}{78}$ & $\begin{array}{r}\text { Total } \\
\text { Mo. }\end{array}$ & $\begin{array}{l}\text { Primary Purpose for } \\
\text { Irrediation }\end{array}$ \\
\hline $\begin{array}{l}B L-1 \\
B L-2 \\
B L-3 \\
B L-4 \\
B L-5 \\
B L-8 \\
B L-10 \\
B L-11 \\
B L-12 \\
B L-13 \\
B L-15 \\
B L-16 \\
B L-19 \\
B L-20 \\
B L-21 \\
B L-22 \\
B L-23 \\
B L-24 \\
B L-25 \\
B L-26 \\
B L-27 \\
B L-28 \\
B L-34 \\
B L-35 \\
B L-37\end{array}$ & 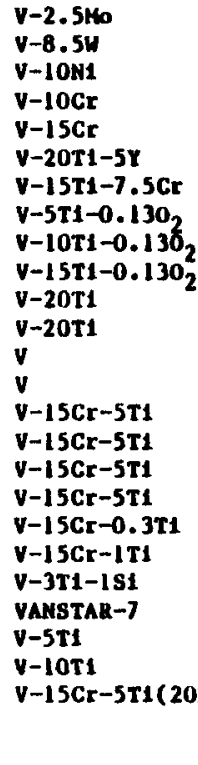 & & $\begin{array}{l}2 \\
2 \\
2 \\
2 \\
5 \\
5 \\
3 \\
3 \\
3 \\
\\
5 \\
5 \\
3 \\
5 \\
5 \\
5 \\
5 \\
5 \\
5 \\
5 \\
5 \\
2\end{array}$ & 3 & $\begin{array}{l}3 \\
3 \\
3 \\
3\end{array}$ & $\begin{array}{l}2 \\
5 \\
2 \\
2 \\
\\
5 \\
3 \\
3 \\
3 \\
5 \\
5 \\
5 \\
5 \\
5 \\
5 \\
5 \\
5 \\
5 \\
5 \\
5 \\
5 \\
5\end{array}$ & $\begin{array}{l}2 \\
5 \\
2 \\
2 \\
\\
5 \\
3 \\
3 \\
3 \\
5 \\
5 \\
5 \\
5 \\
5 \\
5 \\
5 \\
5 \\
5 \\
5 \\
5 \\
5\end{array}$ & $\begin{array}{l}2 \\
2 \\
2 \\
3 \\
1 \\
3 \\
2 \\
2 \\
2 \\
3 \\
3\end{array}$ & $\begin{array}{l}2 \\
2 \\
2 \\
2 \\
2 \\
2 \\
2 \\
2 \\
2 \\
2 \\
2 \\
2 \\
2 \\
2 \\
2 \\
2 \\
2 \\
2 \\
2 \\
2 \\
2 \\
2 \\
2 \\
2 \\
2 \\
4\end{array}$ & $\begin{array}{l}2 \\
2 \\
2 \\
2 \\
2 \\
2 \\
2 \\
2 \\
2 \\
2 \\
2 \\
2 \\
2 \\
2 \\
2 \\
2 \\
2 \\
2 \\
2 \\
2 \\
2 \\
2 \\
2 \\
2 \\
2 \\
4\end{array}$ & $\begin{array}{l}2 \\
2 \\
2 \\
2 \\
2 \\
2 \\
2 \\
2 \\
2 \\
2 \\
2 \\
2 \\
2 \\
2 \\
2 \\
2 \\
2 \\
2 \\
2 \\
2 \\
2 \\
2 \\
2 \\
2 \\
2 \\
4\end{array}$ & $\begin{array}{l}2 \\
2 \\
2 \\
2 \\
2 \\
2 \\
2 \\
2 \\
2 \\
2 \\
2 \\
2 \\
2 \\
2 \\
5 \\
5 \\
5 \\
5 \\
2 \\
2 \\
5 \\
2 \\
2 \\
2 \\
5\end{array}$ & $\begin{array}{r}19 \\
25 \\
19 \\
20 \\
14 \\
8 \\
26 \\
19 \\
19 \\
19 \\
14 \\
123 \\
11 \\
26 \\
26 \\
26 \\
26 \\
29 \\
13 \\
24 \\
29 \\
24 \\
27 \\
26 \\
34 \\
546\end{array}$ & 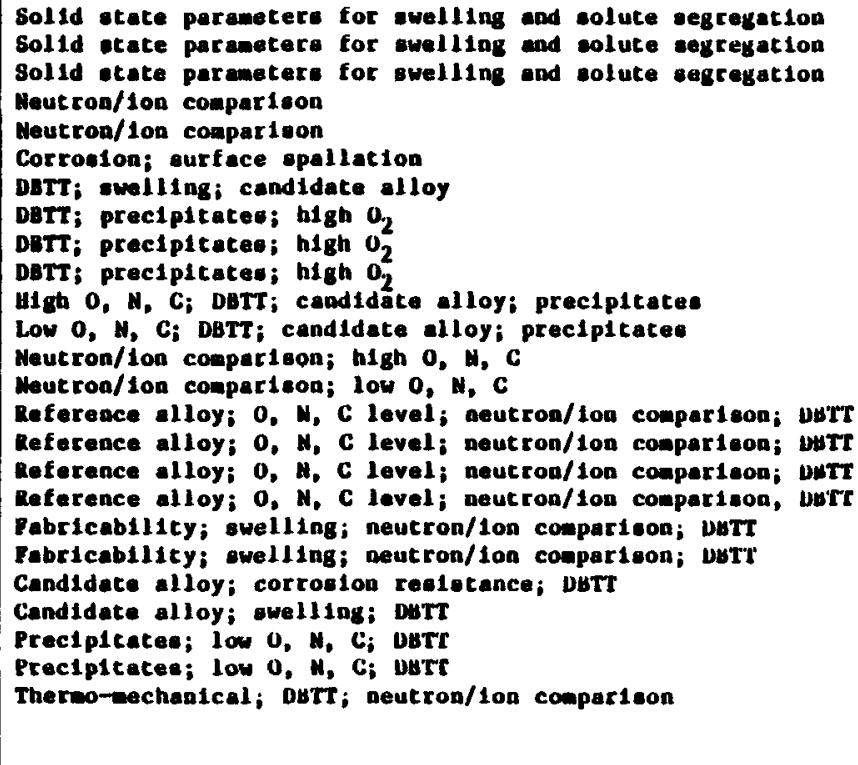 \\
\hline
\end{tabular}

